Article

\title{
Global Warming Implications of the Use of By-Products and Recycled Materials in Western Australia's Housing Sector
}

\author{
Krishna Lawania ${ }^{1, \dagger, *}$, Prabir Sarker ${ }^{2, \dagger}$ and Wahidul Biswas ${ }^{1, \dagger}$ \\ Received: 11 September 2015 ; Accepted: 7 October 2015 ; Published: 12 October 2015 \\ Academic Editor: Jorge de Brito \\ 1 Sustainable Engineering Group, Curtin University, Western Australia 6845, Australia; \\ w.biswas@curtin.edu.au \\ 2 Department of Civil Engineering, Curtin University, Western Australia 6845, Australia; \\ p.sarker@curtin.edu.au \\ * Correspondence: krishna.lawania@curtin.edu.au; Tel.: +61-4-22220831 \\ $\dagger \quad$ The lead author contributed $70 \%$ and co-authors contributed equally for remaining $30 \%$ efforts in writing \\ of the manuscript.
}

\begin{abstract}
Western Australia's housing sector is growing rapidly and around half a million houses are expected to be built by 2030, which not only will result in increased energy and resources demand but will have socio-economic impacts. Majority of Western Australians live in detached houses made of energy intensive clay bricks, which have a high potential to generate construction and demolition (C\&D) waste. Therefore, there is a need to look into the use of alternative materials and construction methods. Due to Western Australia's temperate climate, concrete could not only offer a comfortable living space but an operational energy saving also can be achieved. This paper has assessed the global warming implications of cast in-situ concrete sandwich wall system as an alternative to clay brick walls (CBW) with partial replacement of cement in concrete with by-products such as fly ash (FA) and ground granulated blast furnace slag (GGBFS), natural aggregate (NA) with recycled crushed aggregate (RCA), natural sand (NS) with manufactured sand (MS) and, polyethylene terephthalate (PET) foam core as a replacement to polystyrene core for construction of a typical $4 \times 2 \times 2$ detached house in Perth. Life cycle management (LCM) approach has been used to determine global warming reduction benefits due to the use of available by-products and recycled materials in Western Australian houses.
\end{abstract}

Keywords: clay bricks; cast in-situ sandwich walls; fly ash; GGBFS; RCA; PET foam; GHG emissions

\section{Introduction}

\subsection{Sustainable Built Environment}

Global warming impact, resource scarcity and waste generation are some predominant environmental impacts of modern civilization. Australia's current per capita carbon footprint (23.1 tonnes of $\mathrm{CO}_{2} \mathrm{e}-$ ) and ecological footprint (6.3 global hectares) are approximately 5 and 3.5 times higher than the global average [1,2] mainly due to rapid population and economic growth [3].

Globally, the resource intensive building sector annually consumes $25 \%$ of the wood harvest, $40 \%$ of stone, sand and gravel, and $16 \%$ of water [4]. In order for building sector to achieve sustainability, the overall approach has to change from the use of non-renewable resources to use of renewable resources and from reduction of waste to reuse and recycling of waste [5]. The use of low impact, renewable and recyclable building materials and the reusability of industrial by-products for 
construction purposes should be prioritised in the design, construction and management to achieve environmentally sustainable infrastructure [6,7].

The building sector in Australia contributes to $20 \%$ and $23 \%$ of country's annual energy and GHG emissions, respectively [8,9]. As a result, global warming impact and embodied energy consumption are commonly used key indicators to assess the environmental performance of building sector [10-13]. Australia's housing sector is energy and carbon intensive because a majority of Australians prefer to live in detached houses made of energy intensive clay bricks $[14,15]$ and due to rapid population growth, this sector is expected to grow rapidly from 8.7 million houses in 2010 to 12 million houses by 2030 [16]. During this period, about 15\% (460,000 houses) of these new houses will be constructed in Western Australia alone. Additionally, the building sector in Australia is generating about 20 million tonnes of $C \& D$ wastes annually [17] of which the clay brick itself accounts for 16\% [18] and these wastes contain huge amount of embodied energy [19]. Australian residential building sector's GHG emissions are growing at 1.3\% annually [8] which will impede Australia to meet $60 \%$ GHG emissions reduction target by 2050 .

The strategies need to be developed for the reduction of energy intensive clay bricks and associated C\&D wastes and two possible ways to attain these strategies are to design alternative wall systems requiring less materials and the replacement of virgin materials with recyclates.

It is therefore, imperative to develop an environmental tool that will enable engineers, developers and planners to estimate the GHG emissions and embodied energy saving benefits of the use of alternative wall systems and by-products. Life Cycle Assessment (LCA) tool has been utilized widely to assess the life cycle GHG emissions and embodied energy consumption of the infrastructure industries $[10,13,20,21]$ and to identify further environmental improvement opportunities. This tool captures the overall environmental impacts of a product, process or services from mining, production, assembly, operation, to end of life and thus making the LCA a unique approach in the suite of environmental management tools [22,23].

This paper has considered the current practice of clay brick wall house (CBWH) in Perth as a case study. A LCM framework has been developed to reduce the GHG emissions and embodied energy consumption associated with the construction and use of CBWH.

Firstly, this paper presents GHG emissions and embodied energy consumption of CBWH in Perth, Western Australia. Secondly, GHG emission and embodied energy consumption saving potential associated with the use of alternative wall system have been estimated. Thirdly, the use of by-products and recyclates has been considered to further reduce the environmental impacts. Finally, some other indirect environmental benefits that will result from the reduction of virgin and energy intensive materials use have been estimated.

\subsection{Life Cycle Management Framework}

The LCM framework for this study as shown in Figure 1, integrates LCA tool with the widely used industrial tool known as Nationwide House Energy Rating Scheme (NatHERS) tool [24-26] and strategies involving the utilization of less material intensive wall system, by-products and recyclates in housing sector in Western Australia. This LCM framework will enable to estimate the environmental implications of the use of by-products and recyclates in concrete walls in building construction. The information on materials and energy required during mining to material production, transportation of material to construction site, construction activities and use stages have been considered to conduct this LCA analysis. Since the demolition and disposal of wastes to landfill or their recycling or reuse of the demolition wastes are not considered, it is best termed as a streamlined LCA (SLCA) [10,27].

The life time of the house has been considered as 50 years following Islam and TBA [28,29]. The layout and design of a typical $4 \times 2 \times 2$ ( 4 bedrooms, 2 bathrooms and 2 car parks) detached CBWH in Perth has been utilized to estimate the amount of materials and energy required during pre-construction and construction stages of building life. The energy required for heating, 
cooling, lighting and hot water over the life of the house has been calculated using NatHERS tool (V2.0.2.13SP2). The inputs required for all stages of building life have been estimated to develop a life cycle inventory (LCI), which is a pre-requisite for carrying out a life cycle assessment. The data from LCI have been inserted into SimaPro 8.02 LCA software to calculate GHG emissions and embodied energy consumption benefits associated with the reduction of virgin materials in houses. The use of less material intensive wall system and by-products and recyclates can substantially reduce material consumption and associated environmental impacts.

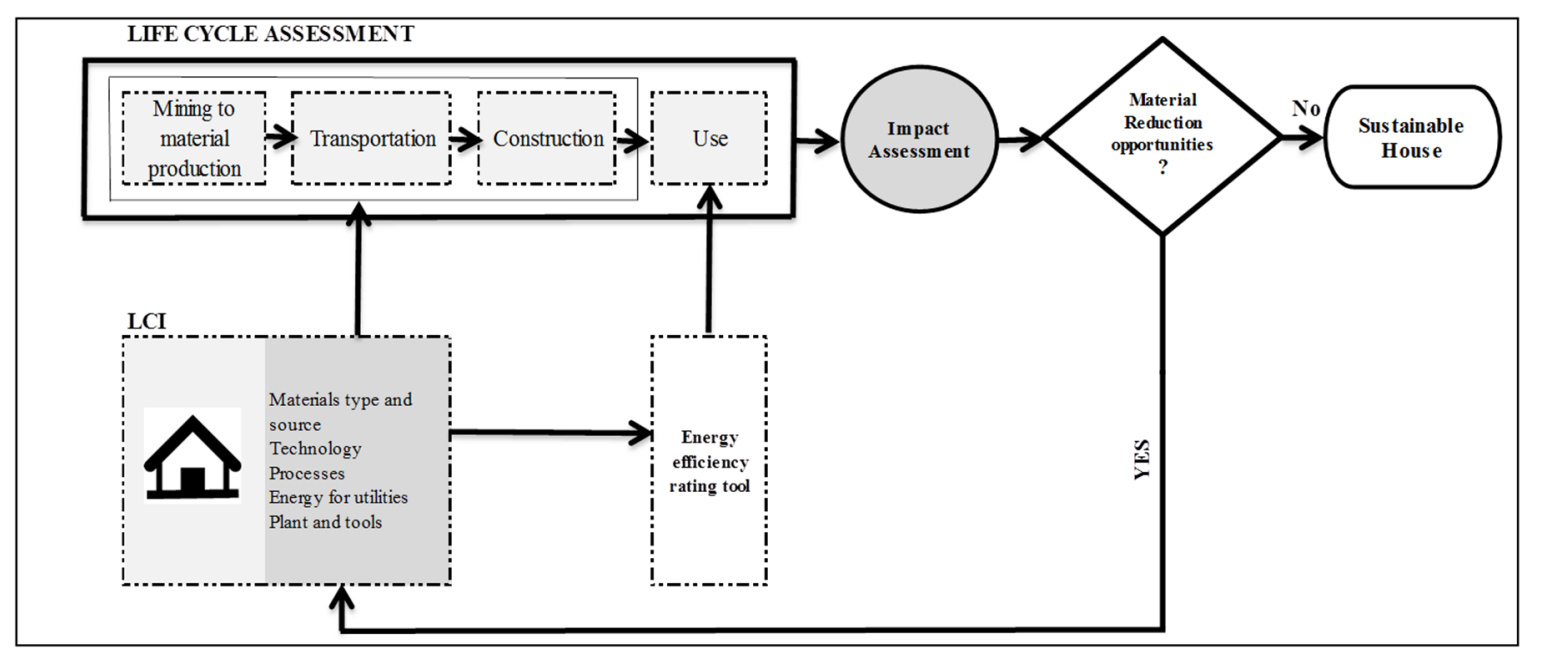

Figure 1. Life cycle management (LCM) framework.

\subsubsection{Streamlined Life Cycle Assessment}

This SLCA has employed the four steps of ISO 14040-44 [23,30]: (1) goal and scope definition; (2) inventory analysis; (3) impact assessment; and (4) interpretation (as presented in the "Results" section of this report) in order to calculate the global warming implications of the use of by products and recycled materials for the construction of houses in WA.

\section{Goal and Scope}

The goal is to assess the life cycle global warming and embodied energy consumption implications of the use of less material intensive wall system, by-products and recycled materials in residential buildings of Western Australia. The functional unit for this study is the construction and use of a typical $4 \times 2 \times 2$ house. The system boundary for this study is limited up to use stage only.

Only GHG emissions and embodied energy consumption have been considered for this study as these are two predominant impacts resulting from the building sector as these impacts have been considered by other studies $[10,13]$. Other associated environmental impacts i.e., acidification, eutrophication, human and eco-toxicity, are insignificant compared to aforementioned impacts [29]. The loose furniture, services, accessories and, external site developments have been excluded from this study as they are not linked to the performance of the building.

\section{Life Cycle Inventory}

A detailed LCI of a typical house in Perth consisting of detailed information on the Bill of Quantities, transportation of construction materials ( $\mathrm{km}=$ tonne $\times \mathrm{km}$ travelled), and energy required for plants and tools at site during construction stage and energy consumed during use stage were generated using detailed drawings, sources of materials, data sheets and AccuRate software. Table 1a,b show the life cycle inventory of this $4 \times 2 \times 2$ detached CBWH. 
Table 1. (a) Materials used for the construction of the typical current practice of clay brick wall house $(\mathrm{CBWH})$ in Perth; (b) Energy used for the construction stage of a typical CBWH in Perth.

\begin{tabular}{|c|c|c|c|c|c|c|c|c|}
\hline Sr. No. & Material & \multicolumn{2}{|c|}{ Location } & Amount & Unit & \multicolumn{2}{|c|}{$\begin{array}{c}\text { Average } \\
\text { Distance }(\mathbf{k m})\end{array}$} & tkm \\
\hline 1 & Virgin sand & \multicolumn{2}{|c|}{ Neerabup/The Lakes } & 21.15 & $\mathrm{~m}^{3}$ & \multicolumn{2}{|c|}{50} & 1797.75 \\
\hline 2 & Polythene sheet & \multicolumn{2}{|c|}{ Canning Vale } & 0.07 & $\mathrm{~m}^{3}$ & \multicolumn{2}{|c|}{30} & 1.31 \\
\hline 3 & Mesh \& bar reinforcement & \multicolumn{2}{|c|}{ Bibra Lake } & 253.69 & $\mathrm{~m}^{2}$ & \multicolumn{2}{|c|}{30} & 19.03 \\
\hline 4 & Ready mix concrete & \multicolumn{2}{|c|}{ Canning Vale/Belmont } & 32.65 & $\mathrm{~m}^{3}$ & \multicolumn{2}{|c|}{30} & 2350.62 \\
\hline 5 & Clay bricks & \multicolumn{2}{|c|}{ Middle Swan/Hazelmere } & 48.52 & $\mathrm{~m}^{3}$ & \multicolumn{2}{|c|}{30} & 2838.42 \\
\hline 6 & Brickie sand & \multicolumn{2}{|c|}{ Neerabup/The Lakes } & 5.69 & $\mathrm{~m}^{3}$ & \multicolumn{2}{|c|}{50} & 484.05 \\
\hline 7 & Cement & \multicolumn{2}{|c|}{ Munster } & 2.63 & tonne & \multicolumn{2}{|c|}{30} & 78.75 \\
\hline 8 & Lime & \multicolumn{2}{|c|}{ Kwinana/Munster } & 0.91 & tonne & \multicolumn{2}{|c|}{30} & 27.20 \\
\hline 9 & Metal lintels & \multicolumn{2}{|c|}{ Malaga/Wangara } & 0.58 & tonne & \multicolumn{2}{|c|}{30} & 17.41 \\
\hline 10 & Aluminium windows & \multicolumn{2}{|c|}{ Belmont/Maddington } & 1.43 & tonne & \multicolumn{2}{|c|}{30} & 43.04 \\
\hline 11 & Metal door frames & \multicolumn{2}{|c|}{ Maddington } & 0.18 & tonne & \multicolumn{2}{|c|}{30} & 5.40 \\
\hline 12 & Roof Timber & \multicolumn{2}{|c|}{ Rockingham } & 7.50 & $\mathrm{~m}^{3}$ & \multicolumn{2}{|c|}{30} & 123.75 \\
\hline 13 & Roof Tiles & \multicolumn{2}{|c|}{ Middle Swan/Hazelmere } & 290.40 & $\mathrm{~m}^{2}$ & \multicolumn{2}{|c|}{30} & 435.60 \\
\hline 14 & Bat Insulation for Roof & \multicolumn{2}{|c|}{ Canning Vale } & 264.00 & $\mathrm{~m}^{2}$ & \multicolumn{2}{|c|}{30} & 14.26 \\
\hline 15 & Gyprock boards \& cornices & \multicolumn{2}{|c|}{ Canning Vale } & 264.00 & $\mathrm{~m}^{2}$ & & & 59.40 \\
\hline 16 & Plaster sand & Neerabup/ & he Lakes & 5.19 & $\mathrm{~m}^{3}$ & 5 & & 440.76 \\
\hline 17 & Door shutters & Armadale/L & bra Lake & 0.74 & $\mathrm{~m}^{3}$ & 3 & & 11.14 \\
\hline 18 & Ceramic floor and wall tiles & Osborne Park & Fremantle & 2.09 & $\mathrm{~m}^{3}$ & & & 184.58 \\
\hline & & & (a) & & & & & \\
\hline Main A & tivities & & Sub-Acti & & & & Energy & Unit \\
\hline Excava & on and compaction & & Bobcat an & oller con & tor ope & tion & 9 & Hrs. \\
\hline Loadin & of excavated soil into trucks & & Front end & ader oper & & & 3 & Hrs. \\
\hline Mortar & Mixing for brick work and rer & dering & Electricity & onsumptio & y Mort & Mixer & 60 & kWh \\
\hline Lifting & f bricks/lintels/roof beams & & Fork Lift & eration & & & 20 & Hrs. \\
\hline $\begin{array}{l}\text { Cutting } \\
\text { nailing, }\end{array}$ & $\begin{array}{l}\text { of bricks, timber, steel and til } \\
\text { grinding \& sanding }\end{array}$ & s, drilling, & Electricity & nsumptio & y Hanc & tools & 60 & kWh \\
\hline Cart aw & ay of excavated soil and cons & uction waste & Transport & eration & & & 3409 & $\mathrm{tkm}$ \\
\hline
\end{tabular}

Impact Assessment

The GHG emissions and embodied energy consumption assessment of the house consists of two steps. In the first step, total GHG emissions and energy consumption in each process are calculated, and then in the second step they are converted to $\mathrm{CO}_{2}$ equivalent $\left(\mathrm{CO}_{2}\right.$ e-) for $\mathrm{GHG}$ emissions impact and to GJ (giga joule) for embodied energy consumption.

Step 1: The LCI data were entered into SimaPro 8.02 [31] LCA software. Each input was linked to relevant library in the SimaPro 8.02 software. The libraries in this software contain the emission factors of energy, materials and transportation inputs for estimating the environmental impacts. The libraries of local products or Australian emission factor databases have been selected to represent local conditions. In the absence of local database in the software, new library databases have been created by obtaining the information on raw material and energy consumptions from local reports. When local information were unavailable for developing libraries of these materials, Ecoinvent Unit Process (EUP) libraries have been used for assessing GHG emissions [32].

Step 2: Once the inputs in the inventories have been linked to the relevant libraries in the software, the Australian GHG method was used to estimate the GHG emissions and the Cumulative Energy Demand method was used to determine the embodied energy consumption of CBWH in Perth including the breakdown of GHG emissions and embodied energy consumption to help identify the "hotspot(s)".

\subsubsection{Application of Cleaner Production Strategies}

Once the SLCA of a CBWH in Perth has been performed, Cleaner Production Strategies (CPS) have been applied to further reduce material consumption and associated environmental impacts. Cleaner production is an integral, necessary component for achieving sustainable development and 
it helps in increasing the productive use of natural resources, minimizing generation of waste and emissions and avoiding risk to people and communities [33,34]. The cleaner production initiatives are applied to processes, products and services to increase efficiency and reduce negative environmental impacts [35]. Two main CPS that are mainly helpful in the reduction of virgin materials consumption in buildings have been considered.

\subsubsection{Product Modification Cleaner Production Strategy}

This strategy involves the replacement of clay brick walls by a less material intensive wall system. A number of wall systems such as autoclaved aerated concrete block masonry, pre-cast concrete wall panels, stud walls and sandwich wall panels that can potentially be used in Australian building sector [18] have been investigated. Because of its high thermal mass and material saving reasons, the currant analysis has considered cast in-situ concrete sandwich walls (CCSW) as a potential replacement of CBW. The CCSW system has been successfully used in Europe, Middle East and Asia, where its popularity is gradually increasing. Additionally, this wall system has successfully been trialled in the eastern states of Australia [36] and complied with the BCA (Building Code of Australia) requirements. However, no initiatives are being taken in WA to build houses using CCSW.

The CCSW system consists of a welded wire space frame integrated with an expanded polystyrene (EPS) insulation core with thin layers of concrete sprayed on either side through shotcrete process after placing in position [36]. This system provides combination of both lightweight and thermal mass, built-in insulation, resistance to earthquake and fire, low moisture absorption and constructability [37]. In addition, the structural efficacy of this system for different construction applications has been established through various analytical and experimental studies [38-43].

An external CCSW that consists of $100 \mathrm{~mm}$ insulation core sandwiched within two layers of $50 \mathrm{~mm}$ thick concrete on either faces and internal walls consists of $50 \mathrm{~mm}$ insulation core sandwiched within two layers of $40 \mathrm{~mm}$ thick concrete on either faces has satisfied the Building code of Australia (BCA) requirements [44]. All non-wall elements, fixtures and features remain the same as of a clay brick wall house.

Whilst the replacement of CBW with CCSW could reduce GHG emissions and embodied energy consumption, there are further opportunities for reducing these impacts by replacing constituents of concrete with by-products and recyclates. The use of by-products helps in converting the linear system of production into close loop system of production by avoiding quarrying activities for virgin material and by reducing landfill area.

\subsubsection{Recycling Strategy}

The constituents of conventional cement concrete were partially substituted by combination of by-products including, fly ash (FA), ground granulated blast furnace slag (GGBFS), recycled crushed aggregates (RCA) and manufactured sand (MS) and the replacement of polystyrene core with polyethylene terephthalate (PET) foam manufactured from post consumed PET bottles for sandwich wall.

\section{Substitution of Concrete Constituents with By-Products and Recyclates}

Three main ingredients of concrete, including cement, aggregates and sand have been considered for replacement with by-products and recyclates to further reduce the amount of virgin materials.

As per Australian Cement Industry Federation report, the GHG emission intensity of per tonne cement manufacturing in 2012-2013 was $700 \mathrm{~kg} \mathrm{CO}_{2}$ e- [45]. Therefore, there is a need for substitution of cement in concrete with supplementary cementitious materials (SCM) with the one with low carbon footprint while maintaining the structural performance and integrity. FA and GGBFS can potentially be used as SCM in a structurally sound manner for the production of concrete [46]. FA is a pozzolanic material, which hardens by reacting with the calcium hydroxide released during 
the hydration of portland cement whereas GGBFS react with water to form hardened binder in the presence of portland cement due to its latent hydraulicity [46].

The second major constituent of concrete is crushed rock aggregate involving energy intensive crushing processes. The use of RCA produced from C\&D waste could not only help reduce the amount of GHG emissions associated with energy consumption and landfill area but it could reduce the air-borne $\mathrm{CO}_{2}$ emissions as well [47]. The third major constituent of concrete is fine aggregate or natural sand. The MS, which is a by-product of crushed rock aggregate, could partially substitute the scarce natural sand resources [47], thereby avoiding additional processing in relation to quarrying and transporting natural sand. Whilst the conversion of MS to workable construction material would require processing; it is worth investigating into the environmental benefits associated with the replacement of natural sand with MS.

Structural and Environmental Implications of By-Products and Recyclates in Concrete

Table 2, show the percentage range of existing constituents that can potentially be replaced with by-products and recyclates, and have also been successfully trialed to study the mechanical and structural behavior and performance, such as compressive and tensile strength, permeability, shrinkage, and durability.

Flower and Sanjayan, Malhotra, Mehta and Dhir (as cited by O'Brien) [48] suggested that the substitution of FA with Portland cement reduces the embodied GHG emissions of concrete. Nath and Sarker $[49,50]$ suggested that $30 \%-40 \%$ cement can be replaced with FA for high strength concrete and a further adjustment in the concrete mix can increase strength, reduce shrinkage and improve permeability properties. For high strength concrete, the risk of thermal cracking can be avoided by replacing cement with $40 \%$ FA [51]. Berndt [52] investigated various properties such as compressive and tensile strengths, elastic modulus, coefficient of permeability and durability in chloride and sulphate solutions of $40 \mathrm{MPa}$ concrete mixes having no cement substitution, $50 \%$ cement replaced with FA, 50\% and 70\% cement replaced with GGBFS, and 50\% cement replaced equally with FA and GGBFS, and all mixes with natural and recycled aggregates. The concrete mixes containing $50 \%$ GGBFS have the best overall mechanical properties and durability for both natural aggregate and RCA [52]. In a $25 \mathrm{MPa}$ concrete mix, where FA is combined with RCA, it not only improves the mechanical properties, and durability performance but helps to overcome negative effects associated with the use of RCA [53].

Table 2. Percentage replacements of concrete constituents considered for various studies.

\begin{tabular}{|c|c|c|c|c|c|}
\hline \multirow[t]{2}{*}{ Concrete Grade } & \multicolumn{2}{|c|}{ Cement Substitution } & \multirow{2}{*}{$\begin{array}{c}\begin{array}{c}\text { Aggregate } \\
\text { Substitution }\end{array} \\
\text { RCA }\end{array}$} & \multirow{2}{*}{$\begin{array}{c}\begin{array}{c}\text { Sand } \\
\text { Substitution }\end{array} \\
\text { MS }\end{array}$} & \multirow{2}{*}{ References } \\
\hline & FA & GGBFS & & & \\
\hline $40 \mathrm{MPa}$ & $25 \%-50 \%$ & $25 \%-70 \%$ & & & Berndt, 2009 [52] \\
\hline $40 \mathrm{MPa}$ & $30 \%$ & $50 \%-80 \%$ & & & Elchalakani et al., 2014 [54] \\
\hline $35 \mathrm{MPa}$ & & $20 \%-40 \%$ & & & Arivalagam, 2014 [55] \\
\hline $50 \mathrm{MPa}$ & $30 \%-40 \%$ & & & & Nath and Sarker, 2011 [50] \\
\hline $62-68 \mathrm{MPa}$ & $30 \%-40 \%$ & & & & Sarker and Mckenzie, 2009 [51] \\
\hline $25-32 \mathrm{MPa}$ & $25 \%$ & $40 \%$ & & & Flower and Sanjayan, 2007 [56] \\
\hline $32 \mathrm{MPa}$ & & $70 \%$ & & & Crossin, 2015 [57] \\
\hline $30 \mathrm{MPa}$ & & & $65 \%$ & & Marinkovic et al., 2010 [58] \\
\hline $40 \mathrm{MPa}$ & $40 \%$ & & $25 \%-100 \%$ & & Ahmed, 2012 [59] \\
\hline $30-35 \mathrm{MPa}$ & $30 \%$ & & $70 \%-85 \%$ & & Corinaldesi and Moriconi, 2009 [60] \\
\hline $30-60 \mathrm{MPa}$ & & & & $100 \%$ & Chow et al., 2013 [61] \\
\hline $30 \mathrm{MPa}$ & & & & $20 \%-80 \%$ & Naveenth and Satheeshkumar, 2015 [62] \\
\hline $20 \mathrm{MPa}$ & & & & $20 \%-100 \%$ & Jadhav and Kulkarni, 2012 [63] \\
\hline $50 \mathrm{MPa}$ & & & & $30 \%-100 \%$ & Sheng-Dong et al., 2015 [64] \\
\hline $60 \mathrm{MPa}$ & $35 \%$ & $55 \%$ & $50 \%-100 \%$ & & Kou et al., 2011 [65] \\
\hline $25 \mathrm{MPa}$ & & & $25 \%-100 \%$ & $35 \%-45 \%$ & Etxeberria et al., 2010 [66] \\
\hline $20 \mathrm{MPa}$, & & & & & \\
\hline $\begin{array}{l}45 \mathrm{MPa}, \\
65 \mathrm{MPa}\end{array}$ & & & $100 \%$ & & D Pedro et al., 2014 [67] \\
\hline
\end{tabular}


The physical properties of RCA can only enable it to be applied in low-to-middle strength structural concrete $[58,68]$. On the other hand, FA aggregate that is obtained by sintering and crushing process and slag aggregate has not only been found to be lighter and stronger than natural aggregate but also possesses lower thermal conductivity $[69,70]$. Though, the increase of RCA may lower the 28 days compressive strength of concrete, but after a period of time, the strength will be higher than that of concrete with NA [71].

MS does not contain organic impurities and, its use in concrete reduces the demand for water and super plasticizer due to presence of microfines and increases the strength without changing the portion of cement in concrete [61,64,72]. Additionally, the blending of MS with natural sands improve workability of concrete and is effective in reducing the level of microfines in the fine aggregate used in the concrete mix as opposed to microfines in MS [73]. By substituting $20 \%$ to $60 \%$ of natural sand by MS in concrete, the strength of concrete increases proportionately $[63,74]$ and optimum strength may be achieved with $40 \%-60 \%$ substitution $[62,64]$.

Australia produced 12.3 million tonnes of fly ash in 2013 out of which $52 \%$ was utilized and in addition to new ash being produced every year there is stock of more than 400 million tonnes of fly ash [75]. As per Australasian (Iron \& Steel) Slag Association report, approximately 1.3 million tonnes of slag was produced in year 2009 and the slag will remain available in substantial amount as long as iron is produced in Australia [76]. In year 2010, Australia produced around 1.3 million tonnes of recycled aggregate [77]. Approximately $30 \%$ of the quarry production is crushed fine, which can further be processed to obtain manufactured sand suitable for concrete [73].

On the basis of the above mentioned findings, following conclusions were drawn for developing compositions of concrete utilizing FA, GGBFS, RCA and MS with conventional materials:

- Up to $30 \%$ of cementitious material and $40 \%$ of natural aggregate (NA) and $40 \%$ of natural sand (NS) could be substituted with FA, GGBFS, RCA and MS with minor adjustments in concrete mix design for various combinations with acceptable structural performance.

- The changes in market and products may affect the constant supply of by-products and therefore it is important to consider a number of structurally sound compositions to suit to any situation during the time of resource scarcity. As a result, seventy two possible compositions (one current/conventional + seventy one alternatives) of concrete have been considered for determination of possible GHG emissions saving implications of this research.

- The cementitious material is divided in to six groups as $100 \%$ OPC, $70 \%$ OPC $+30 \%$ FA, $70 \%$ OPC $+20 \%$ FA $+10 \%$ GGBFS, 70 $\%$ OPC $+15 \%$ FA $+15 \%$ GGBFS, $70 \%$ OPC $+10 \%$ FA + $20 \%$ GGBFS, and 70\% OPC $+30 \%$ GGBFS. Each of these cementitious composition has been used for four aggregate compositions including 100\% NA, 60\% NA + 40\% RCA, 70\% NA + $30 \%$ RCA, and $80 \% \mathrm{NA}+20 \%$ RCA, where each of these aggregate compositions are further sub-divided in to three sand categories each as $100 \%$ NS, $60 \%$ NS $+40 \%$ MS, and $80 \%$ NS + $20 \%$ MS each respectively. Therefore, the total number of compositions of concrete considered in this study is $(6 \times 4 \times 3)$ or 72 as shown in Figure 2 .

Accordingly, 72 different LCIs have been developed for determining the GHG emissions and embodied energy consumption of 72 compositions of concrete for construction of a CCSWH in Perth.

Once aforementioned CPS have been incorporated into LCI, SLCA has been carried out to estimate the amount of life cycle GHG emissions and embodied energy consumption that can be avoided by using recyclates, sandwich wall and by-products. 


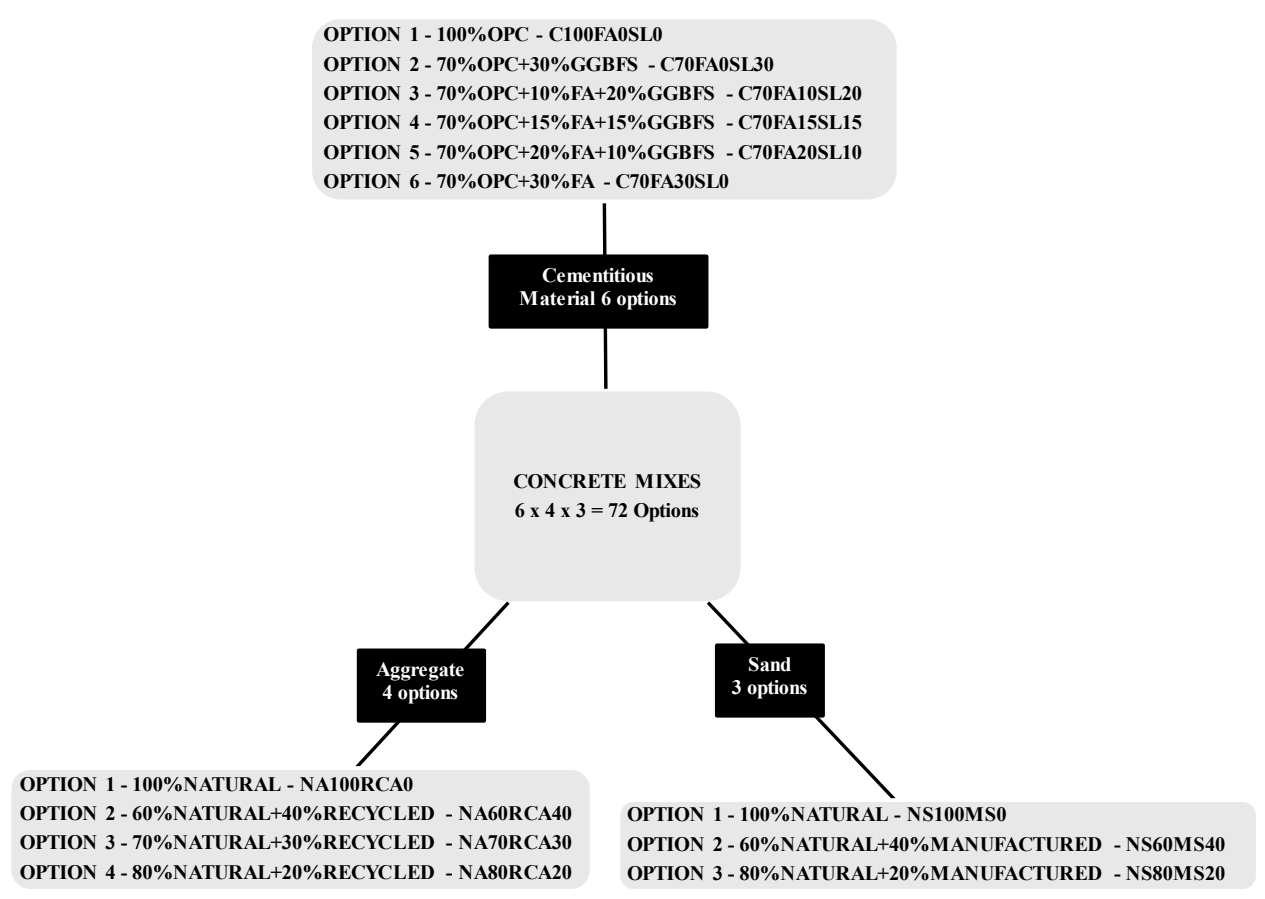

Figure 2. Concrete mixes with varying \% of substitutions.

\section{Results and Discussion}

\subsection{GHG Emission and Embodied Energy Consumption Assessment of WA's Current Building Practice}

The results of SLCA show that life cycle GHG emissions from mining to material production, transportation, construction, and usage stages for a typical CBWH of $243 \mathrm{~m}^{2}$ area are 444.87 tonnes $\mathrm{CO}_{2}$ e-. Figure 3a shows the breakdown of GHG emissions in terms of stages wherein home appliances that accounted for the largest share (39.34\%) of the total GHG emissions have been considered to be the main hotspot. The wall and non-wall elements (pre-construction and construction activities) also contribute significant portion of GHG emissions (11.37\%). Clay bricks $(41 \%)$, and concrete $(23.02 \%)$ have been found to be the top two carbon intensive materials during mining to material production stage (Figure $3 b$ ). All other materials such as ceramic tiles, doors, windows, steel, timber, roof tiles, and mortar together contributed to the remaining GHG emissions (i.e., $35 \%$ ).

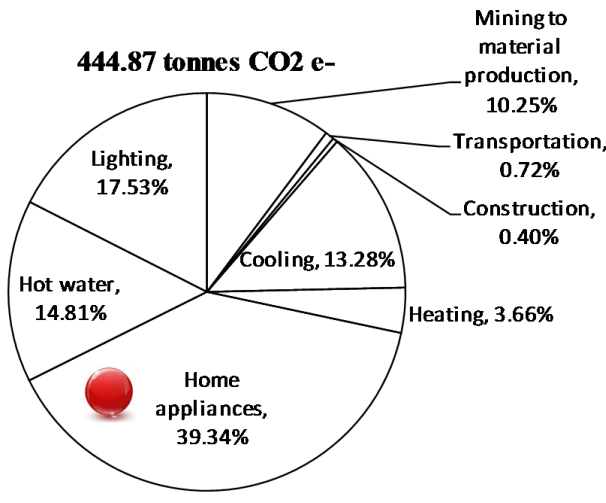

a)

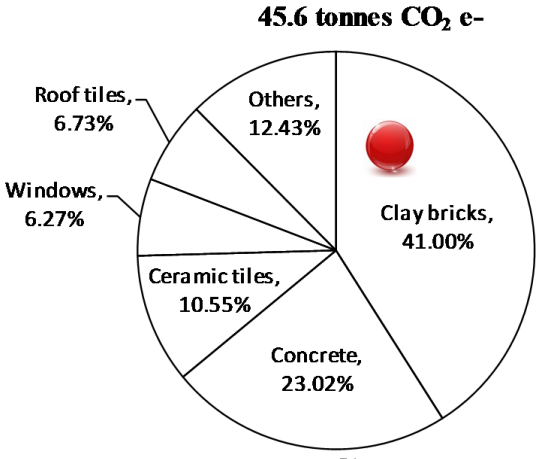

b)

Figure 3. Breakdown of GHG emissions in terms of inputs (a) mining to use (b) mining to material production stage only. 
The results of SLCA show that life cycle embodied energy consumption from mining to material production, transportation, construction, and usage stages for a typical CBWH of $243 \mathrm{~m}^{2}$ area is 6.3 TJ. Similar to GHG emissions trends, the home appliances with a share of 35.89\% of embodied energy consumption have been considered as main hotspot. The share of wall and non-wall elements (pre-construction and construction activities) is $13.14 \%$ (Figure 4a). Clay bricks (40.46\%) have been found to be the most energy intensive construction material (Figure $4 b$ ).

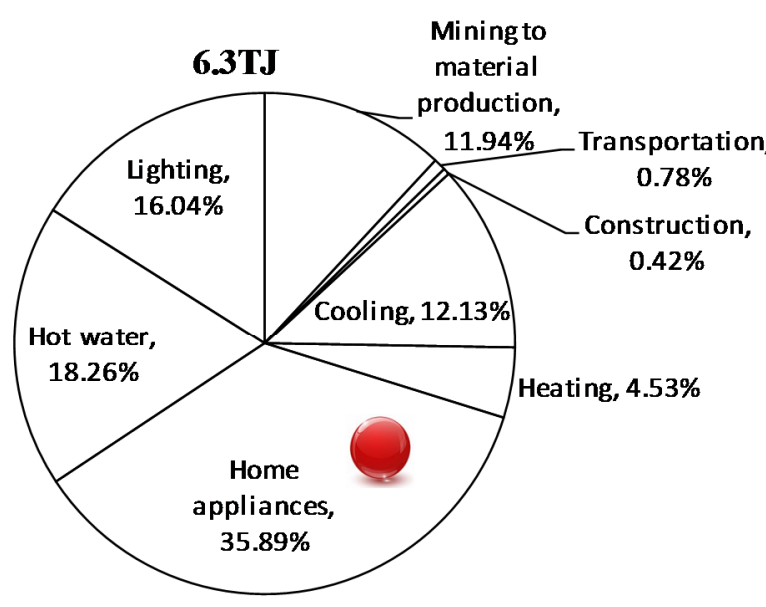

a)

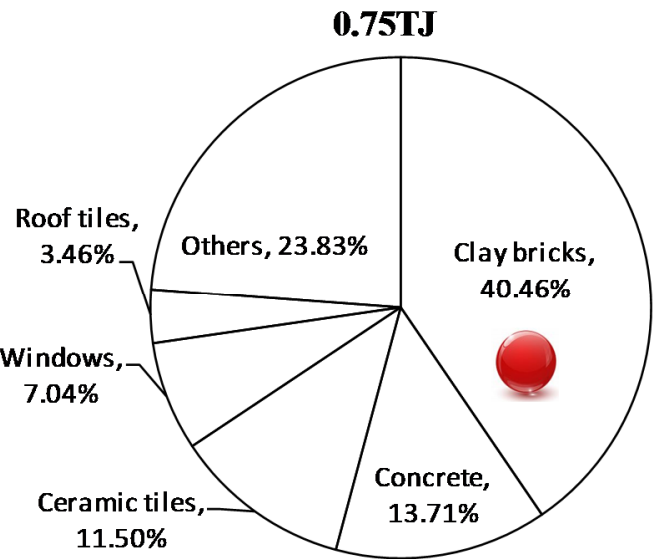

b)

Figure 4. Breakdown of embodied energy consumption in terms of inputs: (a) mining to use (b) mining to material production stage.

Thus, cast in-situ sandwich wall house (CCSWH) has been considered that will not only avoid the use of carbon intensive clay bricks, it will also increase the thermal performance of the existing buildings.

\subsection{GHG Emissions and Embodied Energy Consumption Implications of the Use of Cast In-Situ Sandwich Wall Systems}

Another SLCA analysis has been carried out for cast in-situ sandwich wall house (CCSWH) by taking material saving and thermal performance changes into account while maintaining shape and size of typical CBWH. The LCI data show that the energy required for heating and cooling can potentially be reduced by $58.45 \%$ and $18.73 \%$ respectively and also the material consumption can be reduced by $18.16 \%$ (47.47 tonnes). The results of SLCA as presented in Table 3 show that the life cycle GHG emissions and embodied energy consumption from mining to material production, transportation, construction, and usage stages for a typical CCSWH are 415.81 tonnes $\mathrm{CO}_{2}$ e- and 5.84TJ, respectively. Therefore, the replacement of CBW with CCSW could reduce the GHG emissions and embodied energy consumption by $5.8 \%$ and $5.5 \%$, respectively. Additionally, 51.1\%, 21.83\%, $14.35 \%, 20.25 \%$, and $36.36 \%$ of the GHG emission can be reduced from heating, cooling, mining to material production, transportation, and construction stages respectively. This replacement has no GHG emissions implications associated with the use of home appliances, lighting, and hot water as these appliances were assumed to be unchanged. Further improvement of CCSWH can be considered by incorporating by-products and recyclates in concrete.

The embodied energy consumption also follows similar reduction trends as the saving associated with heating, cooling, mining to material production, transportation, and construction stages are $50.88 \%, 21.86 \%, 15.98 \%, 20.08 \%$, and $36.74 \%$ respectively. The reason for this reduction is mainly due to the avoidance of energy intensive clay bricks and increased thermal performance of the envelope. Table 3 shows that GHG emissions from home appliances still accounts for the largest share (42.09\%) of the total GHG emissions and have been identified as the main hotspot. Similar to GHG emissions 
trends, the home appliances with a share of $35.89 \%$ of embodied energy consumption have been considered as main hotspot but the main focus of this study is to reduce environmental impacts through material of construction.

Table 3. Breakdown and comparison of GHG emissions and embodied energy consumption in terms of inputs for CBWH and cast in-situ sandwich wall house (CCSWH).

\begin{tabular}{|c|c|c|c|c|c|c|}
\hline \multirow{2}{*}{ Stage } & \multicolumn{3}{|c|}{ GHG Emissions (tonnes $\mathrm{CO}_{2} \mathrm{e}-$ ) } & \multicolumn{3}{|c|}{ Embodied Energy (TJ) } \\
\hline & CBWH & CCSWH & $\%$ Saving & CBWH & CCSWH & $\%$ Saving \\
\hline Mining to material production & 45.60 & 39.06 & $14.35 \%$ & 0.75 & 0.63 & $15.98 \%$ \\
\hline Transportation & 3.21 & 2.56 & $20.25 \%$ & 0.05 & 0.04 & $20.08 \%$ \\
\hline Construction & 1.76 & 1.12 & $36.36 \%$ & 0.03 & 0.02 & $36.74 \%$ \\
\hline Cooling & 59.10 & 46.20 & $21.83 \%$ & 0.76 & 0.60 & $21.86 \%$ \\
\hline Heating & 16.30 & 7.97 & $51.10 \%$ & 0.29 & 0.14 & $50.88 \%$ \\
\hline Home appliances & 175.00 & 175.00 & $0.00 \%$ & 2.26 & 2.26 & $0.00 \%$ \\
\hline Hot water & 65.90 & 65.90 & $0.00 \%$ & 1.15 & 1.15 & $0.00 \%$ \\
\hline Lighting & 78.00 & 78.00 & $0.00 \%$ & 1.01 & 1.01 & $0.00 \%$ \\
\hline Total & 444.87 & 415.81 & $6.53 \%$ & 6.30 & 5.84 & $7.17 \%$ \\
\hline
\end{tabular}

\subsection{GHG Emissions and Embodied Energy Consumption Implications of the Use of by-Products} and Recyclates

The LCI of CCSW has been modified to assess the environmental impacts of concrete made of different percentages of FA, GGBFS, RCA, MS and conventional materials. The results of SLCA shows that the use of by-product and recyclates in concrete can save a maximum of $25.91 \%$ (5.11tonnes $\mathrm{CO}_{2}$ e-) GHG emissions (Figure 5) and a maximum of $23.44 \%$ (43.34 GJ) embodied energy consumption (Figure 6) in comparison to the conventional concrete mix during the life cycle of the house. Similarly, a comparative LCA study of $1 \mathrm{~m}^{3}$ of various $40 \mathrm{MPa}$ concrete mixes using combination of supplementary cementitious material and aggregates that was carried out by RMIT shows that the GHG emissions and embodied energy consumption of concrete utilizing supplementary cementitious material and aggregates are $12 \%-49 \%$ and $10 \%-42 \%$ lower than the conventional concrete of same grade respectively [78]. O'Brien et al. [48] suggested that even if FA is transported up to $11,000 \mathrm{~km}$ by articulated truck, $47,000 \mathrm{~km}$ by rail and $54,000 \mathrm{~km}$ by sea for replacing cement in concrete, the net GHG emissions will still be lower than that of conventional concrete. Therefore, the results of this study are within the range of similar studies conducted in Australia.

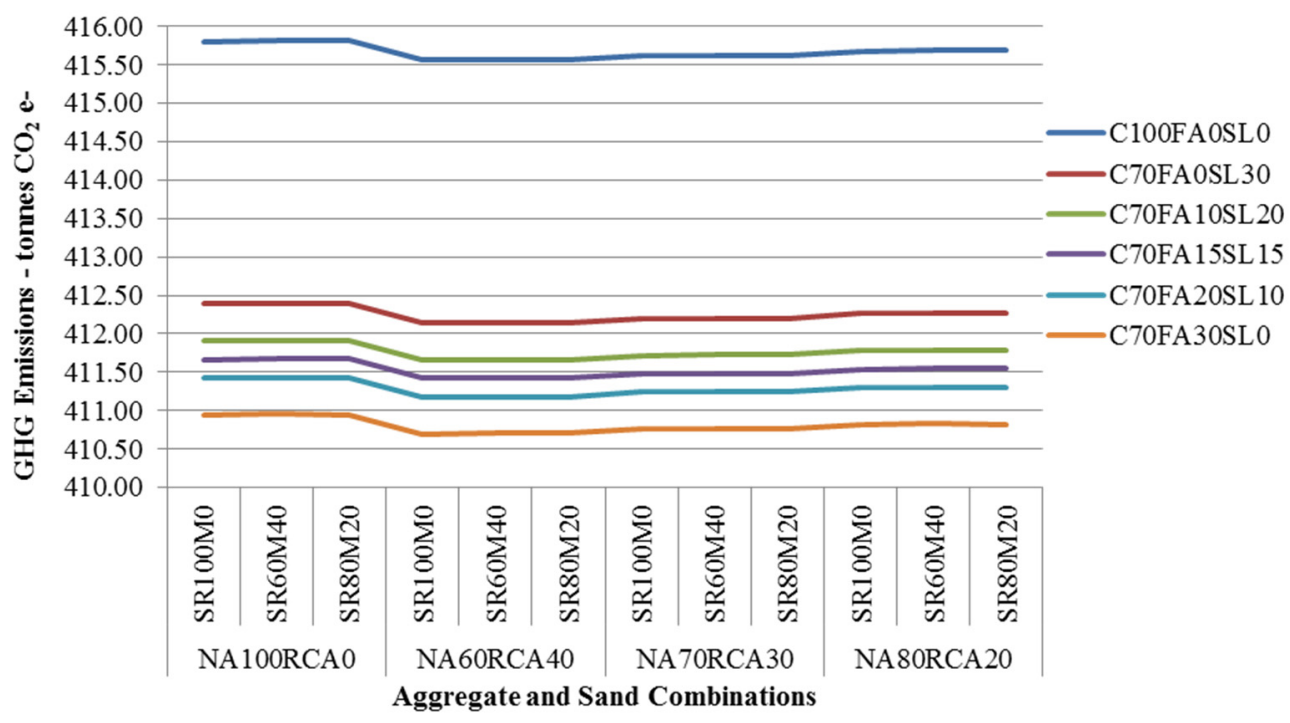

Figure 5. GHG Emissions of CCSWH using by-products for concrete. 


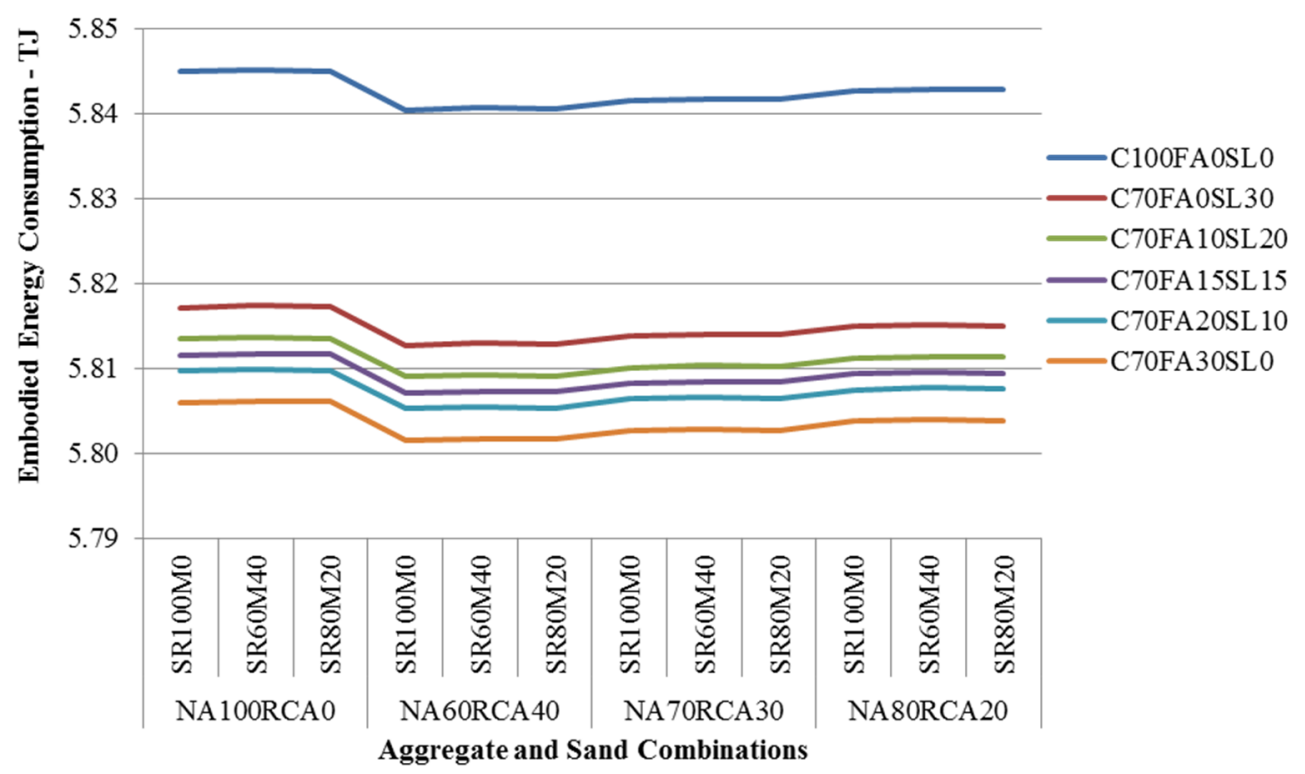

Figure 6. Embodied Energy consumption of CCSWH using by-products for concrete.

From the analysis of results, it is observed that the concrete with a composition of $70 \%$ OPC + $30 \% \mathrm{FA}+60 \% \mathrm{NA}+40 \% \mathrm{RCA}+100 \% \mathrm{NS}$ could offer maximum amount of GHG emissions and embodied energy reduction. Even though, GGBFS and FA both are by-products but FA has slightly higher GHG emissions reduction potential because additional energy is consumed for grinding of granulated blast furnace slag. For 100\% OPC concrete mixes, the changes in aggregate and sand compositions have minor impact on emissions. However, as the SCM are introduced, the GHG emissions and embodied energy consumption reduced significantly. This clearly shows that cement is highly energy intensive component of the concrete. An insignificant increase in GHG emissions $(0.01 \%$ to $0.03 \%)$ and embodied energy consumption $(0.05 \%$ to $0.14 \%)$ are observed when NS is partially substituted with MS in concrete mixes for all cementitious and aggregate compositions. The reason for this increase is due to the fact that an additional energy is consumed for making MS suitable for concrete, [79]. However, there are benefits from minimizing the waste and natural resource depletion [58].

Further analysis of results shows that the concrete mixes having aggregate composition of $60 \% \mathrm{NA}+40 \%$ RCA have higher GHG emissions and embodied energy consumption reduction potential while mixes having $80 \% \mathrm{NA}+20 \%$ RCA compositions have lower potential. Table 4 shows the GHG emissions and embodied energy consumption mitigation potential based on average values for each cementitious group.

Table 4. Concrete mix wise GHG emissions and embodied energy consumption mitigation potential.

\begin{tabular}{ccc}
\hline Concrete Mix Compositions with & \multicolumn{2}{c}{$\%$ Mitigation Potential } \\
\cline { 2 - 3 } All Aggregate Groups and Sand sub-Groups & GHG & Embodied Energy \\
\hline Conventional concrete mix with 100\% OPC & - & - \\
Concrete mix with 70\% OPC and 30\% GGBFS & $17.47 \%$ & $15.19 \%$ \\
Concrete mix with 70\% OPC, 10\% FA and 20\% GGBFS & $19.92 \%$ & $17.23 \%$ \\
Concrete mix with 70\% OPC, 15\% FA and 15\% GGBFS & $21.15 \%$ & $18.26 \%$ \\
Concrete mix with 70\% OPC, 20\% FA and 10\% GGBFS & $22.37 \%$ & $19.28 \%$ \\
Concrete mix with 70\% OPC, 30\% FA & $24.82 \%$ & $21.32 \%$ \\
\hline
\end{tabular}

The concrete mixes having 30\% cement substituted with FA provide maximum mitigation opportunity but other combinations with GGBFS also contribute to substantial reduction opportunity. 
Considering the availability constraints of these by-products, the above combinations offer a flexible solution.

Post consumed plastic bottles made of polyethylene terephthalate (PET) can be used either as a constituent of concrete or as a replacement of polystyrene core [80-82]. In normal conditions, PET is a non-degradable material and due to its large molecules, known micro-organisms are unable to consume it [83]. Sonia [84] suggested that recycling of PET into foam structure provides a durable insulation and core for sandwich structures. As per Australian national plastics recycling survey in 2013-2014, the recovery and recycling rate of PET was 54.8\% [85]. Therefore, the use of post consumed plastic bottles in WA building industries could potentially increase the recovery rate and reduce the generation of solid wastes.

Recycled PET foam is considered as a replacement for polystyrene core for CCSW. The thermal performance of PET foam has been considered while calculating the heating and cooling energy using an AccuRate tool. SLCA analysis has been repeated for CCSWH with PET foam as core. The LCI data show that the energy required for heating and cooling of CCSWH could be further reduced by $7.87 \%$ and $2.02 \%$ respectively. The material consumption is marginally increased by $0.57 \%$ ( 1.22 tonnes). The results of SLCA as presented in Table 5 show that life cycle GHG emissions and embodied energy consumption from mining to material production, transportation, construction, and usage stages for a typical CCSWH that uses PET as core have been estimated to be 413.95 tonnes $\mathrm{CO}_{2}$ e- and 5.79 TJ, respectively. Therefore, the replacement of polystyrene core with PET core could reduce the GHG emissions and embodied energy consumption by $0.45 \%$ and $0.99 \%$, respectively. Additionally, $7.78 \%, 1.95 \%$, and $0.91 \%$ of the GHG emission can be reduced from heating, cooling, and mining to material production stages respectively. This replacement has no impact on GHG emissions associated with home appliances, lighting, and hot water. The GHG emissions associated with the transportation increased by $0.78 \%$, which is negligible. The main reason for this increase is due to the fact that PET foam has higher density than polystyrene core. The embodied energy consumption also follows similar reduction trends as the saving associated with heating, cooling, and mining to material production are $7.86 \%, 1.84 \%$, and $5.67 \%$ respectively.

Table 5. Breakdown and comparison of GHG emissions and embodied energy consumption in terms of inputs for CCSWH, and CCSWH with PET core.

\begin{tabular}{|c|c|c|c|c|c|c|}
\hline \multirow{2}{*}{ Stage } & \multicolumn{3}{|c|}{ GHG Emissions (Tonnes $\mathrm{CO}_{2} \mathrm{e}-$ ) } & \multicolumn{3}{|c|}{ Embodied Energy (TJ) } \\
\hline & CCSWH & CCSWH-PET & $\%$ Saving & CCSWH & CCSWH-PET & $\%$ Saving \\
\hline Mining to material production & 39.06 & 38.70 & $0.91 \%$ & 0.63 & 0.60 & $5.67 \%$ \\
\hline Transportation & 2.56 & 2.58 & $-0.78 \%$ & 0.04 & 0.04 & $-0.51 \%$ \\
\hline Construction & 1.12 & 1.12 & $0.00 \%$ & 0.02 & 0.02 & $0.00 \%$ \\
\hline Cooling & 46.20 & 45.30 & $1.95 \%$ & 0.60 & 0.59 & $1.84 \%$ \\
\hline Heating & 7.97 & 7.35 & $7.78 \%$ & 0.14 & 0.13 & $7.86 \%$ \\
\hline Home appliances & 175.00 & 175.00 & $0.00 \%$ & 2.26 & 2.26 & $0.00 \%$ \\
\hline Hot water & 65.90 & 65.90 & $0.00 \%$ & 1.15 & 1.15 & $0.00 \%$ \\
\hline Lighting & 78.00 & 78.00 & $0.00 \%$ & 1.01 & 1.01 & $0.00 \%$ \\
\hline Total & 415.81 & 413.95 & $0.45 \%$ & 5.84 & 5.79 & $0.99 \%$ \\
\hline
\end{tabular}

The implementation of this strategy could reduce GHG emissions by 1.86 tonnes $\mathrm{CO}_{2}$ e- per house and embodied energy consumption by $0.06 \mathrm{TJ}$ per house.

\section{Summary of GHG and Embodied Energy Savings Due to Use of CPS}

The results of implications of three cleaner production strategies comprising of incorporation of cast in-situ sandwich walls (product modification), partial replacement of cement with FA and GGBFS, NA with RCA and NS with MS (input substitution), and the use of PET foam made of post consumed recycled PET bottles (reuse and recycling) are presented in Table 6. 
It appears from Table 6 that the implementation of product modification, input substitution and re-use and recycle strategies offers GHG emissions reduction of $6.53 \%, 1.15 \%$ and $0.42 \%$ respectively. Similarly, the implementation of product modification, input substitution and re-use and recycle strategies offers embodied energy consumption saving of $7.30 \%, 0.68 \%$ and $0.92 \%$ respectively. The overall GHG emissions reduction is 36.03 tonnes $\mathrm{CO}_{2}$ e- $(8.10 \%)$ and embodied energy consumption saving of $0.56 \mathrm{TJ}(8.90 \%)$ per house.

Table 6. Summary of mitigation potential after implementation of cleaner production strategies (CPS).

\begin{tabular}{|c|c|c|c|c|c|}
\hline \multirow{2}{*}{ Impact } & \multirow{2}{*}{ Original } & \multicolumn{3}{|c|}{ Mitigation Potential Using CPS } & \multirow[b]{2}{*}{ Revised } \\
\hline & & $\begin{array}{c}\text { Product } \\
\text { Modification }\end{array}$ & $\begin{array}{c}\text { Input } \\
\text { Substitution }\end{array}$ & $\begin{array}{l}\text { Re-Use and } \\
\text { Recycle }\end{array}$ & \\
\hline GHG emissions-tonnes $\mathrm{CO}_{2}$ e- & 444.87 & 29.06 & 5.11 & 1.86 & 408.84 \\
\hline Embodied Energy-TJ & 6.30 & 0.46 & 0.04 & 0.06 & 5.74 \\
\hline
\end{tabular}

\section{Conclusions}

The replacement of clay brick walls with cast in-situ sandwich walls for construction of house in Perth as well as subsequent implementation of CPS offers a GHG emissions reduction up to 36.03 tonnes $\mathrm{CO}_{2} \mathrm{e}$ - and embodied energy consumption saving up to $0.56 \mathrm{TJ}$. The use of by-products is not only able to reduce the environmental impacts but it helps in minimizing the natural resource depletion and requirement of landfill area. Considering the growing demand for large number of houses in Perth, current approach could significantly reduce global warming impacts associated with the construction and use of clay brick houses and building industry can contribute to Australia's commitment of GHG emissions reduction targets by 2050.

Acknowledgments: The authors wish to acknowledge all those, whose direct or indirect valuable comments and information helped greatly.

Author Contributions: The lead author contributed $70 \%$ and co-authors contributed equally for remaining $30 \%$ efforts in writing of the manuscript.

Conflicts of Interest: The authors declare no conflict of interest.

\section{References}

1. Department of the Environment. Australian National Greenhouse Accounts-Quarterly Update of Australia's National Greenhouse Gas Inventory -March 2015; Department of the Environment: Parkes, Australia, 2015.

2. World Wide Fund for Nature. Living Planet Report 2014; World Wide Fund for Nature (WWF): Gland, Switzerland, 2014.

3. Australian Bureau of Statistics. Population Projections, Australia, 2012 (Base) to 2101; Australian Bureau of Statistics: Canberra, Australia, 2013.

4. Joseph, P.; Tretsiakova-McNally, S. Sustainable non-metallic building materials. Sustainability 2010, 2, 400-427. [CrossRef]

5. Kibert, C.J.; Sendzimir, J.; Guy, B. Construction ecology and metabolism: Natural system analogues for a sustainable built environment. Constr. Manag. Econ. 2000, 18, 903-916. [CrossRef]

6. Chwieduk, D. Towards sustainable-energy buildings. Appl. Energy 2003, 76, 211-217. [CrossRef]

7. Williams, J. The role of planning in delivering low-carbon urban infrastructure. Environ. Plan. B Plan. Des. 2013, 40, 683-706. [CrossRef]

8. Australian Sustainable Built Environment Council. Capitalising on the Building Sector's Potential to Lessen the Costs of a Broad Based GHG Emissions Cut; Centre for International Economics: Canberra, Australia, 2007.

9. Australian Building Codes Board. Ncc volume two-Energy efficiency provisions-Second edition. In Handbook—Non Mandatory Document; Australian Building Codes Board (ABCB): Canberra, Australia, 2015. 
10. Biswas, W.K. Carbon footprint and embodied energy consumption assessment of building construction works in western Australia. Int. J. Sustain. Built Environment 2014, 3, 179-186. [CrossRef]

11. Ding, G.K.C. Sustainable construction-The role of environmental assessment tools. J. Environ. Manag. 2008, 86, 451-464. [CrossRef] [PubMed]

12. Horne, R.; Grant, T.; Verghese, K. Life Cycle Assessment: Principles, Practice, and Prospects; Csiro Publishing: Victoria, Australia, 2009.

13. Monahan, J.; Powell, J. An embodied carbon and energy analysis of modern methods of construction in housing: A case study using a lifecycle assessment framework. Energy Build. 2011, 43, 179-188. [CrossRef]

14. Milne, G.; Reardon, C. Materials, Embodied Energy_Your Home Australia's Guide to Environmentally Sustainable Homes, 5th ed.; Commonwealth of Australia (Department of Industry): Canberra, Australia, 2013.

15. State of Environment Report, 2011; Department of Environment, Australian Government: Canberra, Australia, 2011.

16. National Housing Supply Council. The Key Findings of 2011, the State of Supply Report, the Australian Government; National Housing Supply Council: Canberra, Australia, 2011.

17. Department of Environment. National Waste Reporting 2013; Department of Environment, Australian Government: Parkes, Australia, 2013.

18. Reardon, C.; Downton, P.; McGee, C. Materials, Construction Systems-Your Home Australia's Guide to Environmentally Sustainable Homes, 5th ed.; Commonwealth of Australia (Department of Industry): Canberra, Australia, 2013.

19. Biswas, W.K.; John, M.; Robson, S. Life Cycle Assessment of Building Construction Wastes in Western Australia; EarthCare: Perth, Australia, 2008.

20. Sharma, A.; Saxena, A.; Sethi, M.; Shree, V.; Varun. Life cycle assessment of buildings: A review. Renew. Sustain. Energy Rev. 2011, 15, 871-875. [CrossRef]

21. Blengini, G.A. Life cycle of buildings, demolition and recycling potential: A case study in turin, Italy. Build. Environ. 2009, 44, 319-330. [CrossRef]

22. Todd, J.A.; Curran, M.A.; Weitz, K.; Sharma, A.; Vigon, B.; Price, E.; Norris, G.; Eagan, P.; Owens, W.; Veroutis, A. Streamlined Life-Cycle Assessment: A Final Report from the SETAC North America Streamlined LCA Workgroup; Society of Environmental Toxicology and Chemistry (SETAC): Brussels, Belgium; SETAC Foundation for Environmental Education: Pensacola, FL, USA, 1999.

23. International Organization for Standardization. ISO 14040:2006_Environmental Management_Life Cycle Assessment_-Principles and Framework; International Organization for Standardization: Geneva, Switzerland, 2006.

24. Aldawi, F.; Date, A.; Alam, F.; Khan, I.; Alghamdi, M. Energy efficient residential house wall system. Appl. Therm. Eng. 2013, 58, 400-410. [CrossRef]

25. Commonwealth Scientific and Industrial Research Organization. Accurate Sustainability v2.0.2.13sp1, Hearne.software. Hearne Scientific Software Pty Ltd. Auckland, New Zealand, 2013.

26. Morrissey, J.; Horne, R. Life cycle cost implications of energy efficiency measures in new residential buildings. Energy Build. 2011, 43, 915-924. [CrossRef]

27. Bala, A.; Raugei, M.; Benveniste, G.; Gazulla, C.; Fullana-i-Palmer, P. Simplified tools for global warming potential evaluation: When 'good enough' is best. Int. J. Life Cycle Assess. 2010, 15, 489-498. [CrossRef]

28. Islam, H.; Jollands, M.; Setunge, S. Life cycle assessment of residential buildings: Sustainable material options in wall assemblies. In Proceedings of the Chemeca 2010: Engineering at the Edge, Hilton Adelaide, Australia, 26-29 September 2010; Engineers Australia: Barton, Australia, 2010; pp. 3443-3452.

29. Think Brick Australia. LCA of Brick Products, Life Cycle Assessment(LCA) Report; Think Brick Australia: Artarmon, Australia, 2010.

30. International Organization for Standardization. ISO 14044:2006-Environmental Management-Life Cycle Assessment-Requirements and Guidelines; International Organization for Standardization: Geneva, Switzerland, 2006.

31. PRé-Consultants. Simapro 8.02 LCA Software, PRé Consultants bv, Amersfoort, The Netherlands, 2013.

32. Hans-Jorg, A. Ecoinvent Unit Processes for Simapro; Life cycle assessment and modelling group: Dübendorf, Switzerland, 2010.

33. United Nations Industrial Development Organization. Manual on the Development of Cleaner Production Policies-Approaches and Instruments; UNIDO CP Programme: Vienna, Austria, 2002. 
34. United Nations Environment Programme. Government Strategies \& Policies for Cleaner Production 928071442-2; United Nations Environment Programme: Nairobi, Kenya, 1994.

35. Van Berkel, R. Cleaner production and eco-efficiency initiatives in western Australia 1996-2004. J. Clean. Prod. 2007, 15, 741-755. [CrossRef]

36. QUESTECH. Evg-3d-Revolutionary Building System. Available online: http://www.questech.com.au (accessed on 21 March 2014).

37. Rezaifar, O.; Gholhaki, M. Nonlinear dynamic behavior of structural frames constructed with 3D wall panels with vertical irregular arrangement. In Proceedings of the 1st International Conference on Seismic Retrofitting, Tabriz, Iran, 20-22 October 2008.

38. Carbonari, G.; Cavalaro, S.; Cansario, M.; Aguado, A. Flexural behaviour of light-weight sandwich panels composed by concrete and eps. Constr. Build. Mater. 2012, 35, 792-799. [CrossRef]

39. Gara, F.; Ragni, L.; Roia, D.; Dezi, L. Experimental tests and numerical modelling of wall sandwich panels. Elsevier Eng. Struct. 2012, 37, 193-204. [CrossRef]

40. Mashal, M.; Filiatrault, A. In Quantification of Seismic Performance Factors for Buildings Incorporating Three-Dimensional Construction System, 15 WCEE-World Conference on Earthquake Engineering, Lisbon, Portugal, 24-28 September 2012.

41. Mousa, M.A.; Uddin, N. Structural behavior and modeling of full-scale composite structural insulated wall panels. Eng. Struct. 2012, 41, 320-334. [CrossRef]

42. Bajracharya, R.M.; Lokuge, W.P.; Karunasena, W.; Lau, K.T.; Mosallam, A.S. Structural Evaluation of Concrete Expanded Polystyrene Sandwich Panels for Slab Application. Available online: http://eprints. usq.edu.au/22601/5/Bajracharya_Lokuge_Karnasena_Lau_ACMSM (accessed on 8 April 2014).

43. Ricci, I.; Palermo, M.; Gasparini, G.; Silvestri, S.; Trombetti, T. Results of pseudo-static tests with cyclic horizontal load on cast in situ sandwich squat concrete walls. Eng. Struct. 2013, 54, 131-149. [CrossRef]

44. Australian Building Codes Board. National construction code series 2015 volume two. In Building Code of Australia Class 1 and Class 10 Buildings; Australian Building Codes Board (ABCB): Canberra, Australia, 2015.

45. Cement Industry Federation Australia. Industry report 2013; Cement Industry Federation Australia: Canberra, Australia, 2014.

46. Cement Concrete and Agregates Australia. Sustainable Concrete Materials, Briefing 11; Cement Concrete and Agregates Australia: Sydney, Australia, 2012.

47. Cement Concrete and Agregates Australia. Sustainable Use of Aggregates, Briefing 19; Cement Concrete and Agregates Australia: Sydney, Australia, 2013.

48. O'Brien, K.; Ménaché, J.; O'Moore, L. Impact of fly ash content and fly ash transportation distance on embodied greenhouse gas emissions and water consumption in concrete. Int. J. Life Cycle Assess. 2009, 14, 621-629. [CrossRef]

49. Nath, P.; Sarker, P.K. Effect of mixture proportions on the drying shrinkage and permeation properties of high strength concrete containing class f fly ash. KSCE J. Civ. Eng. 2013, 17, 1437-1445. [CrossRef]

50. Nath, P.; Sarker, P. Effect of fly ash on the durability properties of high strength concrete. Procedia Eng. 2011, 14, 1149-1156. [CrossRef]

51. Sarker, P.; McKenzie, L. Strength and hydration heat of concrete using fly ash as a partial replacement of cement. In Proceedings of the 24th Biennial Conference of the Concrete Institute of Australia, Sydney, Australia, 17 September 2009.

52. Berndt, M.L. Properties of sustainable concrete containing fly ash, slag and recycled concrete aggregate. Constr. Build. Mater. 2009, 23, 2606-2613. [CrossRef]

53. Lima, C.; Caggiano, A.; Faella, C.; Martinelli, E.; Pepe, M.; Realfonzo, R. Physical properties and mechanical behaviour of concrete made with recycled aggregates and fly ash. Constr. Build. Mater. 2013, 47, 547-559. [CrossRef]

54. Elchalakani, M.; Aly, T.; Abu-Aisheh, E. Sustainable concrete with high volume ggbfs to build masdar city in the UAE. Case Stud. Constr. Mater. 2014, 1, 10-24. [CrossRef]

55. Arivalagan, S. Sustainable studies on concrete with ggbs as a replacement material in cement. Jordan J. Civ. Eng. 2014, 8, 263-270.

56. Flower, D.J.; Sanjayan, J.G. Green house gas emissions due to concrete manufacture. Int. J. Life Cycle Assess. 2007, 12, 282-288. [CrossRef] 
57. Crossin, E. The greenhouse gas implications of using ground granulated blast furnace slag as a cement substitute. J. Clean. Prod. 2015, 95, 101-108. [CrossRef]

58. Marinković, S.; Radonjanin, V.; Malešev, M.; Ignjatović, I. Comparative environmental assessment of natural and recycled aggregate concrete. Waste Manag. 2010, 30, 2255-2264. [CrossRef] [PubMed]

59. Ahmed, S.F.U. Properties of concrete containing construction and demolition wastes and fly ash. J. Mater. Civ. Eng. 2012, 25, 1864-1870. [CrossRef]

60. Corinaldesi, V.; Moriconi, G. Influence of mineral additions on the performance of $100 \%$ recycled aggregate concrete. Constr. Build. Mater. 2009, 23, 2869-2876. [CrossRef]

61. Chow, R.K.K.; Yip, S.W.S.; Kwan, A.K.H. Processing crushed rock fine to produce manufactured sand for improving overall performance of concrete. HKIE Trans. 2013, 20, 240-249. [CrossRef]

62. Naveenth, N.; Satheeshkumar, G. Optimization of partial replacement of natural sand by manufactured sand in concrete. Optimization 2015, 1, 35-38.

63. Jadhav, P.A.; Kulkarni, D.K. An experimental investigation on the properties of concrete containing manufactured sand. Int. J. Adv. Eng. Technol. 2012, 3, 101-104.

64. He, S.-D.; Wang, H.; Li, L. Experimental study on compressive strength of manufactured sand concrete. In Proceedings of the International Conference on Material Science and Application (ICMSA 2015), Suzhou, China, 13-14 June 2015.

65. Kou, S.-C.; Poon, C.-S.; Agrela, F. Comparisons of natural and recycled aggregate concretes prepared with the addition of different mineral admixtures. Cem. Concr. Compos. 2011, 33, 788-795. [CrossRef]

66. Etxeberria, M.; Pacheco, C.; Meneses, J.; Berridi, I. Properties of concrete using metallurgical industrial by-products as aggregates. Constr. Build. Mater. 2010, 24, 1594-1600. [CrossRef]

67. Pedro, D.; de Brito, J.; Evangelista, L. Influence of the use of recycled concrete aggregates from different sources on structural concrete. Constr. Build. Mater. 2014, 71, 141-151. [CrossRef]

68. Galvin, B.; Lloyd, N. In Fly Ash Based Geopolymer Concrete with Recycled Concrete Aggregate, Proceedings of the 25th Biennial Conference of Concrete Institute of Australia (Concrete 2011), Perth, Australia, 12-14 October 2011; pp. 13-14.

69. Kayali, O. Fly ash lightweight aggregates in high performance concrete. Constr. Build. Mater. 2008, 22, 2393-2399. [CrossRef]

70. Beggas, D.; Zeghiche, J. The use of slag stone concrete to improve the thermal performance of light steel buildings. Sustain. Cities Soc. 2013, 6, 22-26. [CrossRef]

71. Silva, R.; de Brito, J.; Dhir, R. The influence of the use of recycled aggregates on the compressive strength of concrete: A review. Eur. J. Environ. Civ. Eng. 2014, 19, 825-849. [CrossRef]

72. Ji, T.; Chen, C.-Y.; Zhuang, Y.-Z.; Chen, J.-F. A mix proportion design method of manufactured sand concrete based on minimum paste theory. Constr. Build. Mater. 2013, 44, 422-426. [CrossRef]

73. Cement Concrete and Agregates Australia. Guide to the Specification and Use of Manufactured Sand in Concrete; Cement Concrete and Agregates Australia: Sydney, Australia, 2008.

74. Pofale, A.; Quadri, S.R. Effective utilization of crusher dust in concrete using portland pozzolana cement. Int. J. Sci. Res. Publ. 2013, 3, 1-10.

75. Ash Development Association of Australia. Annual Membership Survey Results—January-December 2013; Ash Development Association of Australia: Wollongong, Australia, 2014.

76. Australasian (Iron \& Steel) Slag Association. Reference Data Sheet 1-2011 Blast Furnace Slag Aggregate E Cementitious Products; Australasian (Iron \& Steel) Slag Association: Wollongong, Australia, 2011.

77. Sustainable Aggregates South Australia. Recycled Aggregates Bring Carbon Reduction Benefits-Info Sheet; Sustainable Aggregates South Australia: Adelaide, Australia, 2010.

78. Crossin, E. Comparative Life Cycle Assessment of Concrete Blends; Centre for Design, RMIT University: Melbourne, Australia, 2012.

79. O'Flynn, M. Manufactured sands from hardrock quarries: Environmental solution or dilemma for southeast Queensland? Aust. J. Earth Sci. 2000, 47, 65-73. [CrossRef]

80. Foti, D. Preliminary analysis of concrete reinforced with waste bottles pet fibers. Constr. Build. Mater. 2011, 25, 1906-1915. [CrossRef]

81. Intini, F.; Kühtz, S. Recycling in buildings: An lca case study of a thermal insulation panel made of polyester fiber, recycled from post-consumer pet bottles. Int. J. Life Cycle Assess. 2011, 16, 306-315. [CrossRef] 
82. Saikia, N.; de Brito, J. Use of plastic waste as aggregate in cement mortar and concrete preparation: A review. Constr. Build. Mater. 2012, 34, 385-401. [CrossRef]

83. Awaja, F.; Pavel, D. Recycling of pet. Eur. Polym. J. 2005, 41, 1453-1477. [CrossRef]

84. Japon, S.; Leterrier, Y.; Månson, J.A.E. Recycling of poly (ethylene terephthalate) into closed-cell foams. Polym. Eng. Sci. 2000, 40, 1942-1952. [CrossRef]

85. Australian Packaging Covenant. 2012-13 National Plastics Recycling Survey_Final Report; Australian Packaging Covenant: Sydney, Australia, 2014.

(C) 2015 by the authors; licensee MDPI, Basel, Switzerland. This article is an open access article distributed under the terms and conditions of the Creative Commons by Attribution (CC-BY) license (http:/ / creativecommons.org/licenses/by/4.0/). 